\title{
TANTANGAN PROFESIONALISME DAN KESIAPAN GURU MENGIMPLEMENTASIKAN KURIKULUM 2013
}

\author{
Neti Budiwati, Universitas Pendidikan Indonesia \\ watility@gmail.com \\ Sumartini, Universitas Pendidikan Indonesia \\ sumartini@upi.edu \\ Ani Pinayani, Universitas Pendidikan Indonesia \\ ani_pinayani@yahoo.co.id
}

\begin{abstract}
ABSTRAK
Tujuan dari penelitian ini adalah untuk memperoleh gambaran tentang tingkat kompetensi, tingkat komitmen dan tingkat kreativitas guru Ekonomi SMA dalam konteks implementasi Kurikulum 2013. Metode yang digunakan adalah metode survei. Populasi penelitian adalah guru mata pelajaran ekonomi SMA di Kota Bandung, Kabupaten Bandung, Bandung Barat dan Cimahi dan total sampel 78 guru mata pelajaran ekonomi. Analisis data dilakukan dengan menggunakan teknik prosentase (\%), untuk mendeskripsikan data dan informasi sebagaimana yang ingin dicapai. Hasil penelitian menunjukkan bahwa tingkat kompetensi guru Ekonomi SMA di Bandung Raya masih di bawah skor ideal dan hanya sebagian kecil berada pada kategori tingkat kompetensi yang tinggi. Tingkat komitmen dari guru ekonomi SMA di Bandung Raya masih di bawah skor ideal dan hanya bagian kecil pada dalam kategori tinggi. Tingkat kreativitas guru ekonomi SMA di Bandung Raya masih di bawah skor ideal dan hanya sebagian kecil yang berada pada kategori kreativitas tingkat tinggi.
\end{abstract}

Kata kunci: kompetensi, komitmen, kreativitas, Kurikulum 2013

\begin{abstract}
The purpose of this study was to obtain an overview of the level of competence, level of commitment and the level of creativity of high school Economics teachers in the context of the implementation of Curriculum 2013. The method used was a survey method. The study population was a teacher of economic subjects high school in Bandung, Bandung Regency, West Bandung and Cimahi with a total sample of 78 teachers. Data analysis was conducted by using a percentage (\%), to describe the data and information to be achieved. The results showed that the level of competence of teachers Economics High School in Bandung Raya is still below the ideal score and only a small proportion are in the category of a high level of competence. The level of commitment from high school economics teacher in Bandung Raya is still below the ideal score and only a small percentage in the high category. Creativity level high school economics teacher in Bandung Raya is still below the ideal score and only a small proportion are in the category of highlevel creativity.
\end{abstract}

Keywords: competence, commitment, creativity, Curriculum 2013 


\section{PENDAHULUAN}

Isu tentang mutu pendidikan nasional senantiasa mewarnai perbincangan berbagai pihak dan menjadi perhatian pemerintah dan pihak-pihak terkait. Gerakan peningkatan mutu pendidikan telah dicanangkan pada peringatan Hari Pendidikan nasional Tahun 2002. Lahirnya Undang-undang No. 20 tahun 2003 tentang Sistem Pendidikan Nasional dan Undang-undang No. 14 tahun 2005 tentang Guru dan Dosen merupakan jawaban atas gerakan peningkatan mutu pendidikan. Perubahan kurikulum menjadi kurikulum tingkat satuan pendidikan 2006 (KTSP) merupakan pula bagian dari gerakan tersebut. Gerakan peningkatan mutu pendidikan ini jauh dari harapan, sehingga akhirnya setelah melalui berbagai kajian dan implementasi kurikulum di tingkat persekolahan tersebut mengalami perubahan dari KTSP menjadi kurikulum 2013.

Perubahan kurikulum yang selalu dibalut alasan peningkatan kualitas bukanlah persoalan yang sederhana, diperlukan kondisi yang mendukung. Kurikulum 2013 sebagaimana dinyatakan berbagai pihak terkait saat ini bukan lagi untuk diperdebatkan melainkan sudah masuk implementasi, sehingga membawa konsekuensi semua pihak terkait harus siap mengimplementasikannya. Persoalannya saat ini adalah bagaimana kurikulum 2013 tersebut dapat diimplemen-tasikan secara efektif, mengingat kondisi lapangan yang belum siap? Banyak pihak meragukannya dan menganggap terlalu terburu-buru untuk mengimplementasi-kannya."Setiap perubahan kurikulum mestinya memperhatikan kondisi-kondisi uang dialami dalam implementasi kurikulum sebelumnya, tidak bisa serampangan, juga tidak boleh terlalu dipaksakan." (Mulyasa, 2014).

Banyak faktor yang menentukan keberhasilan implementasi kurikulum, seperti faktor guru dan fasilitas/sarana pendidikan. Nana Syaodih (Mulyasa, 2003) menyatakan:'Betapapun bagusnya suatu kurikulum (official), tetapi hasilnya sangat tergantung pada apa yang dilakukan oleh guru dan juga murid dalam kelas (actual)." Ini artinya, keberhasilan peningkatan mutu pendidikan melalui perubahan kurikulum pada akhirnya akan sangat ditentukan oleh guru sebagai pelaksanaan kurikulum. Karena itu, "Siapkah guru mengimplementasikan Kurikulum 2013?" Mengingat peran sentral guru, peranan guru bukan sematamata memberikan informasi melainkan juga mengarahkan dan memberi fasilitas belajar (directing and facilitating the learning) agar proses belajar efektif.

Pertanyaan tersebut muncul mengingat implementasi Kurikulum 2013 sangat berbeda dengan implementasi KTSP. Sebagaimana yang tercantum pada materi sosialisasi Kurikulum 2013, perubahan KTSP menjadi Kurikulum 2013 karena adanya beberapa kelemahan pada KTSP, yaitu : a) Isi dan pesan-pesan kurikulum masih terlalu padat; b) Kurikulum belum mengembangkan kompetensi secara utuh sesuai dengan visi, misi, dan tujuan pendidikan nasional; c) Kompetensi yang dikembangkan lebih didominasi oleh aspek pengetahuan; d) Berbagai kompetensi yang diperlukan sesuai dengan perkembangan masyarakat, seperti pendidikan karakter, kesadaran lingkungan, pendekatan dan metode pembelajaran konstruktifis, keseimbangan soft skills and hard skills, serta jiwa kewirausahaan; e) Kurikulum belum peka dan tanggap terhadap perubahan sosial yang terjadi pada tingkat lokal, nasional maupun global; f) Standar proses pembelajaran belum menggambarkan urutan pembelajaran yang rinci sehingga membuka peluang 
penafsiran yang beraneka ragam dan berujung pada pembelajaran yang berpusat pada guru; g) Penilaian belum menggunakan standar penilaian berbasis kompetensi, serta belum tegas memberikan layanan remediasi dan pangayaan secara berkala.

Paparan di atas membawa konsekuensi profesionalisme guru dalam implementasi Kurikulum 2013. Dalam konteks ini guru sebagai bagian pengembang kurikulum (curriculum developer) maka profesionalitas guru menyangkut bukan hanya penguasaan kompetensi professional dan kompetensi pedagogik yang memadai melainkan pula perlu ditunjang kompetensi personal dan kompetensi sosial, sehingga mampu mengem-bangkan kurikulum setiap mata pelajaran pada tingkat satuan pendidikan yang sesuai dan tepat bagi peserta didiknya, serta memiliki komitmen profesional untuk mengimplementasikan Kurikulum 2013.

Guru mengemban tugas untuk tercipta-nya efektivitas pembelajaran. Untuk efektivitas pembelajaran diperlukan sosok guru yang baik, dalam hal ini adalah yang memiliki standar kompetensi sebagai guru professional (Permendiknas No, 16 Tahun 2007), dan memiliki komitmen terhadap tugas dan tanggung jawabnya, termasuk didalamnya kemampuan dalam mengembang- kan materi ajar atau pengembangan kurikulum.

Penelitian yang dilakukan Somantri, dkk (2007) tentang kesiapan guru ekonomi di wilayah Kota dan kabupaten Bandung dalam mengimplementasikan KTSP, mengemukakan bahwa tinggi rendahnya tingkat efektivitas implementasi KTSP mata pelajaran ekonomi guru SMA secara positif dipengaruhi tinggi rendahnya tingkat kompe-tensi profesional dan kompetensi pedagogik guru. Di sisi lain ditemukan baik kompetensi profesional maupun kompetensi pedagogik guru ekonomi belum pada tingkat yang tinggi, artinya masih perlu upaya untuk dapat meningkatkan kompetensi guru ekonomi. Pertanyaan yang sama juga muncul seiring dengan implementasi Kurikulum 2013, yaitu bagaimana kesiapan guru ekonomi SMA dalam mengimplementasikan Kurikulum 2013 ?

Pertanyaan di atas muncul sekaitan pula dengan temuan Wulandari (2011) yaitu bahwa hanya 42,6 persen dari 2,6 juta orang guru ekonomi atau 1,1 juta orang guru bidang studi ilmu ekonomi yang kini telah memenuhi kualifikasi baik atau berkualitas baik." sehingga menurutnya“..Rendahnya kualifikasi guru ekonomi juga menyebabkan orientasi pendidikan ekonomi di sekolah cenderung pada aspek kognitif siswa dan metode pembelajaran yang membosankan." Kondisi demikian jika dibiarkan maka akan berdampak buruk terhadap hasil belajar peserta didik, lebih jauh lagi terhadap kualitas pendidikan secara keseluruhan.

Hasil ujian nasional yang masih rendah. Perolehan hasil UN mata pelajaran ekonomi pada beberapa SMA Negeri Kota Bandung menunjukkan hasil yang kurang memuaskan, masih rendah yaitu di bawah 6,0 termasuk SMA Negeri yang berada di cluster $1(5,97)$. Jika dibandingkan dengan sekolah lain perolehan tertinggi rata-rata nilai UN untuk mata pelajaran ekonomi diraih oleh sekolah swasta yaitu SMA Kristen 1 BPK Penabur dengan hasilnya sebesar 7,98.

Capaian nilai SMA Kristen 1 Penabur jauh diatas SMA negeri, perolehan tertinggi untuk rata-rata nilai UN pada SMA negeri diraih oleh SMAN 3 Bandung dengan rata-rata nilai 6,57. Kondisi serupa mungkin saja terjadi pada beberapa kota/kabupaten lain yang ada di Jawa Barat, bahkan provinsi lain. Kota Bandung 
merupakan kota pendidikan di Jawa Barat yang menjadi kiblat bagi kota/kabupayen lainnya, sehingga nilai UN di Kota Bandung seringkali dijadikan indikator keberhasilan pendidikan di Jawa Barat.

Satu tahun Kurikulum 2013 diberlakukan dan sudah memasuki tahun kedua. Pertanyannya adalah, "Apakah guru ekonomi telah melaksanakan Kurikulum 2013 sebagaimana mestinya?" Jawaban terhadap pertanyaannya tersebut hingga kini belum diketahui. Sebagaimana telah disinggung di muka, dilihat dari sisi guru, efektif tidaknya implementasi kurikulum akan ditentukan oleh kompetensi yang dimiliki guru. Tanpa dukungan kompetensi yang memadai dari guru maka upaya peningkatan mutu pendidikan melalui perubahan kurikulum menjadi Kurikulum 2013 tidak akan mencapai hasil yang maksimal. Mencermati karakteristik Kurukulum 2013, maka guru dituntut untuk memiliki kreativitas yang tinggi khususnya dalam mendesain pembelajaran.

Mulyasa (2014) mengatakan dari sisi guru "kunci sukses keberhasilan implementasi kurikulum 2013 adalah kreativitas guru, karena guru merupakan faktor penting yang besar pengaruhnya, bahkan sangat menentukan berhasiltidaknya peserta didik dalam belajar. Kurikulum 2013 akan sulit dilaksanakan di berbagai daerah karena sebagian besar guru belum siap. Ketidaksiapan guru itu tidak hanya terkait dengan urusan kompetensinya, tetapi berkaitan dengan masalah kreativitasnya." Oleh karena itu, dalam upaya meningkatkan efektivitas implementasi Kurikulum 2013 perlu dilakukan penelitian yang secara spesifik mengungkapkan tentang kesiapan guru, kompetensi dan komitmen guru dalam kaitannnya dengan implementasi Kurikulum 2013.

Penelitian ini difokuskan pada pemetaan tentang 1) tingkat kompetensi guru ekonomi di Bandung Raya baik kompetensi professional, kompetensi pedagogik, kompetensi personal maupun kompetensi social; 2) Tingkat komitmen guru ekonomi; dan 3) Tingkat kreativitas guru ekonomi pada SMA di Bandung Raya.

Kajian tentang Kurikulum 2013 dipandang sangat urgen, mengingat impelementasi Kurikulum 2013 yang dipandang sebagian besar pihak termasuk para guru masih memiliki kelemahan atau belum siap. Di sisi lain pembelajaran harus tetap berjalan dan peserta didik harus mendapat pelayanan, sehingga siap atau tidak siap Kurikulum 2013 menjadi acuan dalam pembelajaran di tingkat persekolahan yang saat ini sudah masuk tahun ke-2.

\section{METODE PENELITIAN}

Penelitian ini dikategorikan sebagai penelitian eksplanatori yang bersifat noneksperimental. Mengingat jenis dan sifat penelitian ini adalah eksplanatori noneksperimental, maka metode penelitian yang digunakan dipilih metode survei.

Populasi dalam penelitian ini adalah guru mata pelajaran ekonomi SMA yang ada di Kota Bandung, Kabupaten Bandung, Kabupaten Bandung Barat dan Kota Cimahi. Dengan pertimbangan tertentu, maka sampel ditetapkan secara proporsional berdasarkan wilayah. Jumlah sampel sebagai responden sebanyak 78 orang guru mata pelajaran Ekonomi SMA dari 40 sekolah sampel di Bandung Raya.

Teknik pengumpulan data yang diguna-kan dalam penelitian ini adalah teknik komunikasi tidak langsung, yaitu data dikumpulkan dengan menggunakan alat 
yang telah dipersiapkan terlebih dahulu (Surakmad, 1996). Pengumpulan data dilakukan dengan 3 kuesioner yang digunakan yaitu, kuesioner kompetensi, kuesioner komitmen guru dan kuesioner kreativitas guru dalam konteks implementasi Kurikulum 2013. Kuesioner seluruhnya disusun dengan menggunakan penskalaan model Likert 7 poin.

Analisis data dilakukan dengan meng-gunakan teknik prosentase (\%), untuk mendeskripsikan data dan informasi sebagai-mana yang ingin dicapai.

\section{HASIL DAN PEMBAHASAN}

Secara keseluruhan tingkat kompetensi sosial guru Ekonomi SMA di Bandung Raya ada pada tingkat yang tinggi $(6,10)$ atau mencapai $87 \%$ jika dibandingkan dengan skor idealnya. Jika dilihat per indikator, dari tiga indikator yang di ukur maka Kemampuan beradaptasi dengan lingkungan merupakan aspek yang skornya paling rendah $(5,95)$, sedangkan aspek Kemampuan berkomunikasi secara efektif dan santun memiliki skor yang paling tinggi $(6,24)$

Secara keseluruhan tingkat komitmen guru Ekonomi SMA di Bandung Raya ada pada tingkat yang tinggi $(6,02)$ atau mencapai $86 \%$ jika dibandingkan dengan skor idealnya. Jika dilihat per indikator, dari tiga indikator yang di ukur maka Komitmen untuk senantiasa mengembangkan diri dalam menunjang profesi sebagai pendidik merupakan aspek yang skornya paling rendah $(5,76)$, sedangkan aspek Komitmen yang ditunjukkan dengan kebanggan dan mencintai profesi sebagai pendidik memiliki skor yang paling tinggi $(6,24)$

Secara keseluruhan tingkat kreativitas guru Ekonomi SMA ada pada tingkat yang tinggi $(6,14)$ atau mencapai $88 \%$ jika dibandingkan dengan skor idealnya. Jika dilihat per indikator, dari tiga indikator yang di ukur maka Kreativitas dalam melaksanakan pembelajaran merupakan aspek yang skornya paling rendah $(5,76)$, sedangkan aspek Kreativitas dalam merancang pembelajaran memiliki skor yang paling tinggi $(6,24)$

\section{Kompetensi Guru Ekonomi}

Pasal 39 UU No. 20 Tahun 2003 tentang Sistem Pendidikan Nasional menyatakan bahwa "Pendidik merupakan tenaga profesional yang bertugas merencanakan dan melaksanakan proses pembelajaran, menilai hasil pembelajaran, melakukan pembimbing-an dan pelatihan, serta melakukan penelitian dan pengabdian kepada masyarakat, terutama bagi pendidik pada perguruan tinggi." Hasil penelitian menunjukkan bahwa skor rata-rata kompetensi guru Ekonomi SMA di Bandung Raya belum mencapai skor idealnya, hal ini menunjukkan bahwa kompetensi guru belum memenuhi standar sebagaimana dijelaskan Undang-undang tersebut. Hasil ini juga terlihat dari data bahwa hanya sebagian kecil guru mempunyai tingkat kompetensi tinggi. Begitupun bila dilihat per aspek kompetensi guru, baik kompetensi pedagogik, kompetensi professional, kompetensi personal maupun kompetensi social belum mencapai skor ideal.

Jika dilihat per indikator, dari tiga indikator kompetensi profesional yang di ukur maka aspek penguasaan pengembangan materi secara kreatif dari para guru masih rendah dibandingkan dengan dua aspek lainnya maupun dilihat secara total. 
Aspek ini terkait dengan masalah bagaimana guru memilih materi pembeljaran ekonomi sesuai dengan tingkat perkembangan peserta didik, dan mengolah materi pelajaran ekonomi secara kreatif sesuai dengan tingkat perkembangan peserta didik. (Permendikbud No. 16 Tahun 2007). Rendahnya tingkat kompetensi guru dalam aspek ini diduga aspek ini menunjukkan lemahnya tingkat kreativitas guru dalam ekonomi pegembangan materi ajar. Hal ini sejalan dengan temuan lapangan dan penelitian terdahulu yang dilakukan Neti Budiwati (2014), bahwa kebanyakan guru mengajar secara tekstual/konseptual sebagaimana yang tertulis pada buku yang menjadi pegangan.

Berkenaan dengan masalah di atas, untuk meningkatkan kompetensi profesionalnya khususnya dalam aspek pengembangan materi secara kreatif maka guru harus terus berusaha melakukan perbaikan diri, sejalan dengan salah satu prinsip dari Kurikulum 2013, yang menekankan pada penggunaan atau pemanfaat IT, serta beranekaragamnya sumber belajar.

Dari empat indikator yang diamati dalam kompetensi pedagogik, aspek yang masih kurang dibandingkan aspek lainnya yaitu terkait dengan kemampuan melaksanakan kegiatan pembelajaran dan mengevaluasi pembelajaran, sedangkan aspek kemampuan menyusun perencanaan pembelajaran merupakan aspek yang paling baik yang dimiliki guru dibandingkan dengan aspek lainnya yang diamati. Rendahnya aspek melaksanakan pembelajaran dan mengvaluasi pembelajaran diduga terkait dengan adanya perubahan kurikulum yang semula KTSP menjadi Kurikulum 2013, yang secara langsung mempengaruhi kemampuan guru dalam pembelajaran.

Masalah pelaksanaan pembelajaran merupakan inti dari tugas pokok guru bagitupun dengan evaluasi. Aspek melaksnakan terkait dengan kemamuan memilih model, metode, dan tehnik pembelajaran serta menentukan langkahlangkah pembelajaran. Kurikulum 2013 menggunakan pendekatan saintifik yang menuntut guru untuk kreatif memilih dan menggunakan beragam model, metode dan tehnik pembelajaran. Diperlukan kesediaan guru untuk memhami Kurtilas, sehingga harus meluangkan waktu dan perhatian yang banyak, dan ini dianggap sebagian guru sebagai hal yang memberatkan. Evaluasi hasil, baik untuk tes formatif setiap pokok bahasan maupun tes sumatif juga membutuhkan keterampilan tertentu, dimulai dari membuat kisi-kisi soal sampai pada analisis soal dan hasil tes. Dalam Kurtilas aspek evaluasi dipandang sebagai masalah yang berat, Ketidakpahaman guru dalam pelaksanaan evaluasi bisa berdampak buruk terhadap kualitas hasil pembelajaran, karena salah dalam memilih bentuk dan jenis tes bisa berakibat tidak tercapainya tujuan pembelajaran.

Untuk itu maka diperlukan pelatihan untuk meningkatkan diri dalam pelaksanaan evaluasi, baik dilakukan sendiri-sendiri oleh guru maupun secara bersama dalam kelompok kerja baik melalui MGMP Mata pelajaran maupun oleh pihak sekolah. Karena dalam tugasnya di sekolah guru berperan sebagai perancang pengajaran, pengelola pengajaran, penilai hasil belajar siswa, pengarah dan pembimbing murid.

Dalam aspek perencanaan pembelajaran, dapat disimpulkan bahwa guru-guru Ekonomi SMA memiliki kompetensi pedogogik yang baik (tinggi). Tingginya kompetensi pedagogik dalam aspek ini mengisyaratkan sesuatu yang baik, namun dengan syarat perencanaan pembelajaran yang disusun tersebut betul-betul dijadikan sebagai acuan kegiatan pembelajaran. Karena selama ini ada anggapan 
pada sebagian guru bahwa menyusun perencaaan pembelajaran (silabus dan RPP, dahulu Satpel) merupakan kewajiban administarsi belaka, sehingga tidak dijadikan sebagai acuan dalam pelaksanaan pembelajaran. Bila perencanaan pembelajaran yang disusun dapat dipraktekkan, maka diharapkan proses pembejaran akan berjalan efektif dan membuahkan hasil yang maksimal. Hal ini perlu ditanamkan pada setiap guru, agar perencaan pembelajaran yang disusunnya buka sekadar formalitas memenuhi kewajiban administrasi guru.

Kompetensi personal dan kompetensi sosial bila dibandingkan dengan kompetensi profesional dan kompeensi pedagogik memiliki skor yang lebih baik, padahal sesungguhnya yang lebih berperan dalam peembelajaran di kelas adalah kompetensi profesional dan kompetensi pedagogik. Mencermati kondisi ini dapat dikatakan bahwa secara personal dan sosial, sosok guru ekonomi di Bandung Raya sudah mendekati ideal, akan tetapi masih perlu peningkatan.

Pengorganisasian kemampuan yang dimiliki (khususnya kompetensi pedagodik dan kompetensi profesional) memunculkan adanya kaitan dan identifikasi yang jelas antara materi yang akan dikembangkan menjadi bahan ajar dengan rancangan proses belajar yang akan dikembangkan agar materi tersebut menjadi sesuatu yang "learnable" dan efektif untuk mencapai tujuan. Kita dapat membayangkan seandainya seorang guru ekonomi tidak memiliki kedua kompetensi tersebut. Bila ia hanya memiliki kemampuan penguasaan dalam subject matter saja atau hanya menguasai keterampilan mengajar saja, maka tujuan pengajaran yang dilakukannya sulit untuk tercapai. Oleh karenanya kedua kemampuan itu mutlak dimiliki seorang calon atau guru ekonomi (Budiwati dan Permana, 2010), karena peranan guru dalam proses pembelajaran sangat dominan.

\section{Komitmen Guru Ekonomi}

Komitmen pasti akan mendorong rasa percaya diri dan semangat kerja mereka. Seorang guru yang komit dengan pekerjaannya, pasti akan mengusahakan yang terbaik dalam kegiatan pembelajarannya, oleh karena itu komitmen akan memperlancar pergerakan sekolah mencapai goal setting perubahan. Pengamatan terhadap komitmen guru ekonomi SMA di Bandung Raya menunjukkan hasil bahwa skor komitmen mengajar guru belum mencapai skor ideal.

Dilihat per aspek maka aspek komitmen untuk senantiasa mengembangkan diri dalam menunjang profesi sebagai pendidik merupa-kan aspek dengan skor yang rendah dibandinkan dua aspek lainnya. Hal ini mengindikasikan bahwa komitmen guru untuk menjadi guru yang lebih baik lagi atau lebih profesional masih dianggap kurang. Bila dicermati hal ini linier dengan hasil pengamatan terhadap kompetensi guru aspek kompetensi profesional, yaitu rendahnya kemampuan guru dalam mengembangkan materi ajar secara kreatif, begitupun dengan kompetensi pedagogik aspek melaksanakan dan menilai pembelajaran.

Guru selayaknya memiliki komitmen yang tinggi terhadap profesinya, dengan komitmen berarti memiliki tanggung jawab untuk melaksanakan pembelajaran yang bermakna. Karena, berkat usaha guru,maka timbul kegairahan belajar siswa, sehingga memacu belajar lebih keras untuk mencapai tujuan belajar mengajar yang bersumber dari tujuan kurikulum, untuk itu guru idealnya terlibat dalam pengembangan kurikulum.

Untuk dapat menjabarkan/melaksanakan dan mengembangkan kurikulum ekonomi, diperlukan pemahaman mengenai karak-teristik ilmu ekonomi bagi guru 
ekonomi. Dengan memahami karakteristik ilmu ekonomi maka akan membantu guru ekonomi dalam mengorganisasikan pengajarannya secara optimal.

Guru sebagai pendidik professional ditunjukkan dengan kompetensi professional-nya dilihat dari watak, sikap dan nilai, pengetahuan maupun keterampilannya dan ditunjang dengan komitmen terhadap tugasnya. Komitmen guru dalam tugasnya terkait dengan tuga peran utama guru, yaitu sebagai perancang pembelajaran, pelaksana pembelajaran dan penilai pembelajaran.

\section{Kreativitas Guru Ekonomi}

Kegiatan pembelajaran mengandung ciri bahwa kegiatannya mendukung proses belajar siswa, adanya interaksi antara individu dengan sumber belajar, memiliki komponen-komponen tujuan, materi, proses, dan evaluasi yang saling berkaitan. Agar pembelajaran efektif, maka salah satu faktor yang menentukannya adalah daya kreativitas guru. Guru harus kreatif baik pada saat merancang pembelajaran, melaksnakan pembelajaran maupun menilai pembelajaran.

Dalam melaksanakan pembelajaran, proses akan berjalan secara efektif bilamana guru kreatif dalam memilih materi ajar dan mengembangkannya, memilih model/metode/ tehnik pembelajaran serta memilih media dan sumber pembelajaran.

Pengamatan terhadap tingkat kreativitas guru ekonomi SMA di Bandung Raya juga belum mencapai skor ideal. Dilihat per aspek, ketiga aspek yang diamati yaitu kreativitas dalam merancang, melaksanakan dan menilai pembelajaran memiliki skor yang tidak jauh berbeda, tentu saja hasil ini masih kurang memuaskan. Oleh karena itu perlu upaya untuk terus meningkatkan daya kreativitas guru dalam pembelajarannya. Terkait dengan implementasi Kurikulum 2013 yang menuntut capaian kompetensi peserta didik pada ranah berfikir tingkat tinggi, yaitu menganalisis (C4), menilai (C5) dan mengkreasi (C6), maka sudah selayaknya gurunya pun harus memiliki kompetensi yang memadai.

Kreativitas tidak muncul begitu saja atau instan, melainkan membutuhkan waktu dalam proses belajar yang tiada henti. Kreativitas tidak mungkin dimiliki tanpa kemampuan pada tingkat yang dibawahnya. Kreativitas membutuhkan pengetahuan dan kemampuan daya nalar yang tinggi yang memerlukan kerjasama semua pihak. "Proses mengajar yang efektif memang melibatkan kemampuan mempresentasikan suatu topik atau mendemonstrasikan suatu keterampilan sedemikian rupa sehingga para siswa dapat memahami dan menguasai materi tersebut,...Selain itu, proses mengajar efektif melibatkan kemampuan menentukan "posisi" siswa terkait level pembelajaran dan level perkembangannya,...dalam arti mensyaratkan sikap guru seperti mengakomodasi keberagaman latar belakang para siswa, agama, kondisi keluarga, dan juga kekurangan fisik, kognitif, atau perilaku yang mungkin dimiliki para siswa." (Ormrod, 2008). Mengajar merupakan usaha kreatif dari seorang guru dalam hubungannya dengan manejemen kelas, juga dalam hubungannya dengan siswa mereka yang mungkin memiliki variasi kemampuan, bakat, minat dan karakteristik lainnya. Guru yang cerdas atau guru yang berkualitas akan mampu mengkondisikan semuanya, sehingga proses pembelajarannya berjalan efektif. 


\section{SIMPULAN}

Gambaran tingkat kompetensi guru guru ekonomi SMA di Bandung Raya masih dibawah skor ideal dan hanya sebagian kecil yang berada pada kategori tingkat kompetensi yang tinggi. Hal ini bermakna bahwa tingkat profesionalisme guru-guru ekonomi masih perlu ditingkatkan. Gambaran tingkat komitmen guru ekonomi SMA di Bandung Raya masih dibawah skor ideal dan hanya hanya sebagian kecil saja yang berada pada ketegori tinggi. Hal ini bermakna bahwa komitmen guru-guru ekonomi masih perlu ditingkatkan. Sedangkan tingkat kreativitas guru ekonomi SMA di Bandung Raya masih dibawah skor ideal dan hanya sebagian kecil yang berada pada kategori tingkat kreativitas tinggi. Hal ini bermakna bahwa kreativitas guru-gur ekonomi masih perlu ditingkatkan.

\section{DAFTAR RUJUKAN}

Mulyasa. E. (2014). Pengembangan dan Implementasi Kurikulum 2013. Bandung: PT Remaja Rosdakarya (2003). Kurikulum Berbasis Kompetensi: Konsep, Karakteristik dan Implementasi.Bandung: PT. Remaja Rosdakarya

Neti Budiwati. (2014). Pengembangan Model Pembelajaran Berbasis Literasi Ekonomi. Bandung: LPPM UPI

Ormrod. J.E. (2008). Psikologi Pendidikan (Terjemahan Wahyu Idianti, dkk.). Jakaarta: Erlangga

Somantri. S. dkk. (2007). “Tantangan Profesionalisme dan Kesiapan Guru Dalam Mengimplementasikan KTSP, Survey pada Guru Mata Pelajaran Ekonomi SMA”.Jurnal Pendidikan IPS, 2007

Universitas Pendidikan Indonesia. (2010). Re-Desain Pendidikan Profesional Guru. Bandung: UPI Press

Undang-undang Republik Indonesia No. 20 tahun 2003 tentang Sistem Pendidikan Nasional

Undang-undang republik Indonesia No, 14 Tahun 2005 tentang Guru dan Dosen

Wulandari. D. (2011). Wah , Guru Ekonomi Berkualitas Hanya 42 Persen. Online http://mobile,seruu,com/utama/bisnis-a-pendidikan 